\title{
Environmental Regulation, Innovation Capability, and Green Total Factor Productivity: New Evidence from China
}

Chien-Chiang Lee ( $\nabla$ cclee6101@gmail.com )

Nanchang University https://orcid.org/0000-0003-0037-4347

Mingli Zeng

Nanchang University

Changsong Wang

Nanchang University

\section{Research Article}

Keywords: Innovation capabilit, environmental regulations, green total factor productivity, China

Posted Date: November 9th, 2021

DOl: https://doi.org/10.21203/rs.3.rs-962061/v1

License: (c) (1) This work is licensed under a Creative Commons Attribution 4.0 International License.

Read Full License

Version of Record: A version of this preprint was published at Environmental Science and Pollution Research on January 31st, 2022. See the published version at https://doi.org/10.1007/s11356-02118388-0. 
1

5

\title{
Environmental regulation, Innovation capability, and green total factor productivity : New evidence from China
} . . . 8

.

3

4

\author{
Chien-Chiang Lee ${ }^{1,2} *$, Mingli Zeng1, Changsong Wang ${ }^{1,3}$ \\ 1. School of Economics and Management, Nanchang University, \\ Nanchang 330031, Jiangxi, China; \\ 2. Research Center of the Central China for Economic and Social Development, Nanchang \\ University, Nanchang 330031, Jiangxi, China \\ 3. Institute of Agricultural Economics and Information, Jiangxi Academy of Agricultural \\ Sciences, Nanchang 330200, Jiangxi, China
}

\footnotetext{
* Corresponding author. Chien-Chiang Lee, Distinguished Professor, School of Economics and Management, Nanchang University, Nanchang, Jiangxi, China. Contact e-mail: cclee6101@gmail.com (C.-C. Lee).
} 


\section{ABSTRACT}

In recent years, China's economy has experienced a rapid transformation period from rugged economic development to a sustainable economic development style. Increasing green total factor productivity (GTFP) is considered as one of the important signs. The application of innovation capability (ICY) is becoming more and more widely used in modern life. But it is still unclear how ICY can affect GTFP. With increasingly stricter environmental laws and regulations, how environmental regulations (ER) affect GTFP is unclear. This research contributes to the literature on the impact mechanisms of ICY and ER on GTFP using the data on 30 Chinese provinces covering the period from 2006-2017. The results indicate both ICY and ER can effectively promote GTFP. Compared with ER, ICY has obvious heterogeneity on GTFP, that is, the stronger the ICY is, the stronger it promoting effect on GTFP. Next, ICY plays an intermediary role in ER and GTFP, and ER can promote GTFP through ICY. Accordingly, the paper puts forward some policy suggestions, such as optimizing and improving ER policy, unswervingly practicing innovation-driven development strategy, strengthening monitoring and supervision.

Keywords: Innovation capability; environmental regulations; green total factor productivity; China 


\section{Introduction}

Since the $18^{\text {th }}$ CPC National Congress, in order to cope with the development environment changes at home and abroad, grasp the development autonomy and improve the core competitiveness, China has always adhered to the road of independent innovation with Chinese characteristics, then implement the innovation-driven development strategy and the concept of innovative development. However, it should be that problems such as unbalanced and inadequate innovation and development in some regions, the quality and efficiency of innovation are still low, and a weak innovation capability (ICY hereafter) still exists. Some scholars believe patten licenses number is often an important indicator of innovation capability (Zhu et al., 2021; Wang and Wang, 2021). Take this as an example, by the end of 2017, Guangdong province was 332,652, ranking first in China, while Tibet Autonomous Region was 420, accounting for only $1 \%$ of the patent licenses in Guangdong. At the same time, the national proportion of eastern China accounted for $73 \%$, more than twice the sum of patent licenses in the central regions and western regions. The improvement of regional innovation level is the foundation for building an innovative country in an all-round way. The unbalanced and inadequate development of regional ICY has become a practical problem restricting China's implementation of the innovation-driven development strategy (Liu, 2013).

In the early days of China's development, the government did not realize that protecting the environment is as important as economic development, "pollution and then governance" become the basic routine of national economic development. In pursuit of economic interests, areas and regions lack bottom-line thinking and ignore the carrying limits of local ecosystems, making the ecological environment overloaded and causing huge and incalculable losses. Take the growth rate of green total factor productivity (GTFP hereafter) as an example, the annual growth rate of China's total factor productivity (TFP hereafter) in 2016 is 2.3\%, while after considering energy consumption, environmental impact and emission factors, the annual growth rate of GTFP is only $1.15 \%$. With the concept of "clear water and green mountains are gold 
and silver mountains" deeply rooted in the hearts of the people, top-level design and institutional progress have been accelerated, pollution control has been vigorously promoted, green development has been remarkable, and ecological and environmental quality has continued to improve. Environmental regulations (ER hereafter) are an effective way to promote the coordinated development of the economy, ecology and society. So, studying ER is of great significance to green development and high-quality development.

The $18^{\text {th }}$ National Congress of Communist Party of China, the $19^{\text {th }}$ National Congress of Communist Party of China and the $14^{\text {th }}$ Five-Year Plan all clearly emphasized the need to give top priority to ecological development and green development, and to promote high-quality economic development and high-level ecological and environmental protection in a coordinated manner. Measurement and evaluation of green economic development and high-quality economic development are becoming important hot issues in academic circles. The growth rate of TFP and its contribution to its output growth are regarded as the main basis for judging the mode of economic development and the improvement of economic quality (Wang et al., 2009). However, academia often adopts GTFP as a comprehensive and good indicator to measure and evaluate green economic growth, considering it as a green development index that combines economic growth with environmental protection and harmony between man and nature (Zhu, 2019; Liu, 2020; Yu, 2021). But some scholars only study the relationship between individual factors such as ICY and economic development, Wang (2019) focused on the influence of the Internet development on regional total factor energy efficiency and proved that the development of the Internet plays a positive role in promoting the improvement of regional total factor energy efficiency. Or only study the relationship between ER resources and economic development. For example, Li (2021) studies the relationship between economic growth quality, environmental quality and ER, and it is suggested that differentiated ER policies be implemented for different regions in the whole upper, middle and lower reaches of the Yangtze River Economic Belt. None of the above took into account the 
economic impact of ICY and environmental resources on the combination. How do ICY and environmental resources work in the economy? What is the impact mechanism? What role will they play in economic development, and how can they three achieve high-quality economic development? Therefore, clarifying the relationship between ICY, ER and GTFP and analyzing the influence mechanism between the three will help to scientifically evaluate whether the economy has achieved high-quality and green development under the premise of full consideration of the ecological and environmental constraints.

To sum up, it is of great significance to study ICY, ER and GTFP. So, what are the characteristics of GTFP development in China? Will ICY affect GTFP? As a restrictive means for the government to promote the innovation of the green economy, does ER play a regulatory role between the ICY and the GTFP? Compared with the existing studies, this paper has the following contributions and differences: First, the research subjects are more comprehensive. This paper focuses on ICY, ER and GTFP, and explores the influence mechanism. Most of the existing studies often study the relationship between ICY, innovative technology on GTFP or ER on GTFP. Second, the empirical research is more robust. Existing research on ER of GTFP mostly from the perspective of environmental regulation tools or regional competition spillover effect, the mechanism of ER affect GTFP was missing from thorough research, basing on the verification of the non-existing spatial effect, we focus on the moderating and mediating effect analysis of ICY between ER and GTFP and showed mediating effect existed shortage. Third, the calculation of GTFP is relatively scientific. Part of the research only measures GTFP from the perspective of input and output, and ignores the impact of unexpected output on GTFP. However, this paper takes industrial waste water utilization rate, $\mathrm{SO} 2$ utilization rate and industrial solid waste utilization rate as unexpected output, and measures GTFP by using GML model.

Following the introduction, the rest of the article is organized as follows. Section 2 presents a literature review of the existing studies on economic growth, ICY and ER, then introduces the impact mechanism of interaction between these three. Section 3 
describes the variables and data sources and methodology. Section 4 introduces the econometric models applied in this paper and the empirical results and analysis. Section 5 further discusses the empirical results. Finally, the last section summaries the conclusion and put forward corresponding policy implications.

\section{Literature Review}

\subsection{Analysis of the impact mechanism of ICY and GTFP}

There is very rich literature research on ICY to promote economic development and promote the improvement of TFP. One kind of literature focuses on the impact of ICY on regional economic growth, and studies the impact of ICY on regional economic growth from the perspective of technological innovation, factor agglomeration, knowledge spillover (Chun and Lv, 2021; Yamashita, 2021; Zhou et al., 2017; Xu, 2016). It is generally believed that the improvement of ICY contributes to the optimization of labor structure, industrial structure upgrading, innovative technology application, which is conducive to the improvement of TFP (Hu et al., 2020), and thus promote regional economic growth. Another kind of literature directly studied the impact of ICY, technological progress on TFP, from the perspective of regional development differences, Internet development, industrial structure optimization, the influence of ICY on GTFP, this kind of researches consider that ICY plays a significant role in promoting GTFP (Zhou et al., 2019).

On one hand, as the economic development tends to integration, innovation exchanges between regions, innovation activities exchange and cooperation cost reduction, innovation subjects are easier to obtain innovation information and innovation technology, easier to learn and imitate innovation technology, make ICY improving between regions, which optimize the labor structure, promote industrial structure upgrading, and promote economic growth. Meanwhile, with the implementation of the national innovation-driven development strategy, research and development investment, innovation achievements have also been included in new 
performance indicators, local government gradually increase innovation resources, improve the level of innovation output, due to the regional adjacent effect and the competition effect, to form a spatial spillover effect of ICY, thus creating a positive effect on the economy ( $\mathrm{Li}$ and Wang, 2020). On the other hand, due to the influence of regional policy differences, local governments formulate and implement the innovation incentive mechanism according to the local actual situation, resulting in differences in ICY between various regions, so the impact of regional differences on green total factor production is not the same. At the same time, with the development of the Internet, the application of new technologies related to resource utilization, environmental protection, the generation of new materials, new energy and other new industries, as well as new modes of digital economy, directly affect technological progress and technological efficiency, thus affecting the change of GTFP (Wang and Cao, 2019; He et al., 2021).

Hence, this study proposes the following

H1: Innovation capability can advance the improvement of GTFP.

\subsection{Analysis of the impact mechanism of ER and GTFP}

In recent years, China has issued the Law of the People's Republic of China on the Prevention and Control of Air Pollution, the Environmental Protection Law of the People's Republic of China, the Environmental Impact Assessment Law, the Clean Production Promotion Law and other laws and regulations. China's environmental governance depends not only on administrative means, but also on the adjustment of market-oriented economic means. Economic tools such as environmental tax policies, environmental credit policies, environmental poverty alleviation policies, environmental protection industry policies and other economic tools, as well as resource industry agreement, environmental certification plan, environmental leader system of pollutant discharge enterprises can be used as important means and tools for environmental governance. Potter hypothesis thinks that appropriate ER can promote enterprise technological innovation in certain environment, namely "weak" Potter 
hypothesis; appropriate ER can promote the competitiveness of enterprises in certain environment, namely "strong" Potter hypothesis (Porter, 1995; Huang and Liu, 2006). Strong or weak, ER has always been an effective way to solve the externality of environmental pollution. Nameroffet et al. (2004) believes that the government shall develop environmental regulatory policies to support and encourage enterprises to produce green products and services, thus significantly reducing the external additional costs of innovation competition. Song et al. (2016) Show that if the enterprise technological innovation considers environmental protection, it will help to improve environmental governance, and then promote the coordinated development of the economy and the environment (Song and Wang, 2016; He et al., 2021).

On the one hand, with the strengthening of ER, the government has strengthened ER on enterprise production and operation activities through a series of means such as formulating strict environmental protection policies, resource industry agreements and environmental certification programs. This will encourage enterprises to take the following measures to deal with ER: one is to improve production process and technology, reduce pollution emission intensity, improve production efficiency, reduce or inefficient environmental costs, form environmental innovation effect; Second, influenced by the encouraging policies of government ERs, such as green subsidies and capital tilt, enterprises take the initiative to carry out technological innovation to obtain policy subsidy incentives and form innovation compensation effect; third, for projects with high investment, high energy consumption and high pollution, enterprises would consider the strict environmental protection policies, and prefer to choose in green innovation projects and high energy consumption and high pollution projects to form investment screening effect.

Hence, this study proposes the following:

H2 : ER can push the improvement of GTFP.

\subsection{Analysis of the impact mechanism on ICY, ER and GTFP}

About the impact of ER on GTFP (Wu et al., 2020), academia has a large amount of 
literature research. Some use individual indicators for ER measurement, and some, on the basis of building an index system, use the entropy method, principal component analysis and adjustment index to obtain the comprehensive ER index, and carry out empirical analysis and research on them. The research conclusion is roughly divided into three categories: First, ER has a positive effect on GTFP (Yi and Zhang, 2018; Gong et al., 2019; Gong and Li, 2020); Second, in the long run, ER has a negative promoting effect on GTFP (Huang et al., 2018); Third, under the influence of specific types of ERs, GTFP shows a trend of differentiation. That is, command control and incentive ER have a negative impact on GTFP, while public participation ER has a positive impact on GTFP. It is also believed that different ER types and GTFP show inverted "U" type, inverted "N" type and "U" type (Gao et al., 2020; Cai and Zhou, 2017; Shen et al., 2017; Wu and You, 2019); Wang and Zhang, 2020). Therefore, the impact of ER on GTFP presents different characteristics, so is it possible for ER to affect GTFP through other factors? For example, via. ICY, it is assumed that ER can affect the GTFP through ICY.

The research on the influence of ER on GTFP is increasingly mature, and many valuable conclusions have been drawn. However, there is less research on the relationship between ICY, ER and GTFP, and there are even few studies on what mechanism of ERs influence GTFP. To further verify the relationship between ICY, ER together with GTFP, the following hypothesis is put forward:

H3: Innovation capability and ER can simultaneously affect GTFP.

Therefore, on the basis of learning from the existing research results, using panel data of Chinese 30 provinces and cities in the period of 2005 2017, focus on the relationship between ICY, ER and GTFP, combine with the moderating effect and the mediating effect analysis, the impact mechanism is studied, and then put forward policy suggestions accordingly.

\section{Data and methodology}

\subsection{Data}




\subsubsection{Independent variables}

This paper mainly studies the influence mechanism and action path of ER and ICY on GTFP. Therefore, GTFP is particularly important as the explained variable. This paper chooses variables of input elements, expected output and unexpected output etc. and then uses the GML model to calculate the GTFP. Detailed data are as follows:

(1) Input elements $(X)$ : Including capital stock $(K)$, Labor $(L)$ and energy $(E)$. The first one is capital stock. Since there are no official statistics on the capital stock in Chinese provinces, the academic circle mainly uses Zhang et al. (2004) and Shan et al. (2008) to calculate the provincial capital stock. This paper adopts the perpetual inventory method to deal with it (Kong et al., 2021). $K_{i t}=K_{i t-1}\left(1-\delta_{i}\right)+I_{i t}$, Among them, $K_{i t}$ and $K_{i t-1}$ indicate the capital stock during $t$ and $t-1$ period in $i$ provinces respectively, $I_{i t}$ is an actual investment during the $t$ period in $i$ provinces. Based on the practice of Zhang et al. (2004), the total amount of fixed capital formation represents the current investment. According to the Shan (2008) method, the fixed asset price index in 2005 is used as the investment price index to estimate the actual investment from 2005-2017. $\delta_{i}$ is the depreciation rate in $i$ provinces, and is calculated using $10 \%$ in most literature. For the base capital stock in 2005, the sum of the actual investment in 2005 is divided by the depreciation rate plus the actual investment annual growth rate. The second one is labor. This paper uses the number of employees in each province to represent the labor input (Zhou et al., 2019). Third, E is energy. In this paper, various energy consumption indicators of the statistical Yearbook are selected and converted to 10,000 tons of standard coal according to the carbon emission coefficient published by IPCC (Liu et al., 2021), and the total energy consumption represents the energy input of each province (Sun and Yang, 2020). The total amount of fixed capital formation, fixed asset price index and number of employees are from the China Statistical Yearbook, and the total energy consumption data are from the China Energy Statistical Yearbook over the years.

(2) Desired output (Y): The GDP of all provinces will be reduced at the base period of 2005.Data are derived from the China Statistical Yearbook over the years. 
(3) Non-Desired output $(U)$ : Industrial SO2 discharge, total wastewater discharge, industrial solid waste production amount (Zhang and Qiao, 2021). Based on the availability of data, using industrial wastewater utilization rate, $\mathrm{SO} 2$ utilization rate and industrial solid waste utilization rate (Wu et al., 2020). The data comes from the China Environmental Statistics Yearbook and China Environment Yearbook.

\subsection{2 dependent variables and control variables}

The core dependent variables of this paper are ER and ICY, and the control variables are industrial added value, technological progress, industrial structure and urbanization level.

(1) ER. Currently, there are three main ways to measure variables on ER: one is a certain policy implementation as a cutoff (for example, the Action Plan for Air Pollution Prevention and Control), Measured by dummy variables (0-1) (Wang et al., 2021); One is to measure the comprehensive ER index by industrial sulfur dioxide removal rate $(\%)$, industrial smoke (powder) dust removal index $(\%)$, industrial solid waste comprehensive utilization rate $(\%)$, industrial wastewater treatment rate $(\%)$, household waste harmless treatment rate (\%) and adjustment coefficient (Wang et al., 2018), entropy method and adjustment coefficient method are used to measure ER intensity (Wang et al., 2018); One is to measure ER by the proportion of the total investment in environmental pollution control in GDP or the number of environmental events disclosure (Yang et al., 2021). Since some environmental indicators have been calculated as their undesirable output indicators, and in order to avoid endogenous model problems, this paper takes the number of environmental event disclosure as a measure of ER indicators, and takes the proportion of total environmental pollution control investment in GDP as the alternative variable of ER. The data are derived from China Environmental Statistics Yearbook and China Environmental Yearbook over the years.

(2) Innovation capability. Innovation capability has a significant impact on GTFP (Zhang et al., 2021), and the higher the number of regional patent application authorization, the stronger the ICY of the region, the more can promote the use and 
progress of energy-saving technology, and then promote the improvement of GTFP (Wang et al., 2019), so this paper uses the number of patent application authorization as a measure of the technology development index (Wang and Cao, 2019)(Zhang and Qiao, 2021).The patent application authorization data were selected from the China Science and Technology Statistics Yearbook over the years.

(3) Control variable. Considering the possible estimation deviation caused by missing variables (Zhu, 2019; Liu, 2020; Yu, 2021), referring to the relevant literature on ER, ICY and GTFP, combined with the variable screening results, the control variables select industrial added value, technological progress, industrial structure and urbanization level. Among them: industrial added value is expressed by the "GDP of secondary industry"; technological progress is expressed by the "per capita science and technology expenditure"; industrial structure is expressed by the "ratio of tertiary industry to secondary industry output value"; urbanization level is expressed by the over the years.

\subsection{Model setting}

\subsubsection{GML Model}

314 Chung et al. (1997) present the Luenberger productivity index, which considers both reduced input and increased output without choosing the measurement angle, and therefore is much more general than the Malmquist productivity index and the ML productivity index. Referring to Oh. (2005), We use the global ML index to measure total factor energy efficiency (TFP)(Cheng et al., 2020) and decompose it into technical efficiency change (EC) and technological progress (TC) (Oh, 2010).

$$
G T F P_{t}^{t+1}=\frac{1+\vec{D}_{0}^{G}\left(x^{t}+y^{t}+b^{t} ; g^{t}\right)}{1+\vec{D}_{0}^{G}\left(x^{t+1}+y^{t+1}+b^{t+1} ; g^{t+1}\right)}=G E C_{t}^{t+1} \times G T C_{t}^{t+1}
$$

$$
G E C_{t}^{t+1}=\frac{1+\vec{D}_{0}^{t}\left(x^{t}+y^{t}+b^{t} ; g^{t}\right)}{1+{\overrightarrow{D_{0}}}_{0}^{t+1}\left(x^{t+1}+y^{t+1}+b^{t+1} ; g^{t+1}\right)}
$$


$G T C_{t}^{t+1}=\frac{1+\vec{D}_{0}^{G}\left(x^{t}+y^{t}+b^{t} ; g^{t}\right)}{1+\vec{D}_{0}^{t}\left(x^{t+1}+y^{t+1}+b^{t+1} ; g^{t+1}\right)} \times \frac{1+\vec{D}_{0}^{t+1}\left(x^{t+1}+y^{t+1}+b^{t+1} ; g^{t+1}\right)}{1+\vec{D}_{0}^{G}\left(x^{t+1}+y^{t+1}+b^{t+1} ; g^{t+1}\right)}$

Among them: $\vec{D}_{0}^{G}(\cdot)$ is Malmquist function, with the directional vector set

to $\left(g_{x}, g_{y}, g_{z}\right)=(-x, y,-b)$, Thus is to pursue the goal of maximizing expected output, minimizing input and non-expected output, and input and expected output are strongly disposed able or freely disposable, and non-expected output is weakly disposable.

\subsubsection{Panel data model}

Based on the reference of the research (Wang et al., 2020; Wu et al., 2019; Wang et al., 2018; Zhu, 2019), This paper takes GTFP as the independent variable, and ER and ICY as the core dependent variable, and the benchmark measurement model is constructed as follows:

$\operatorname{lnGTFP}_{i t}=\beta_{0}+\beta_{1} * \operatorname{lner}_{i t}+\beta_{2} * \operatorname{lnict}_{i t}+\beta_{3} * \operatorname{lnsec}_{i t}+\beta_{4} * \operatorname{lnte}_{i t}+\beta_{5} *$ lnis $_{i t}+\beta_{6} *$ lnurban $_{i t}+\mu_{i}+\theta_{t}+\varepsilon_{i t}$ (4)

Among them: $i$ and $t$ represent provinces and years, respectively, $\mu_{i}$ and $\theta_{t}$ represent unobservable individual and time fixed effects, respectively, $\varepsilon_{i t}$ represent the random error terms. GTFP indicates the GTFP of the independent variables, erexplains the ER of dependent variables, ict indicates the innovation capability of dependent variables, sec, te, is, urban indicates the industrial added value, technological progress, industrial structure and urbanization level of the control variables respectively.(Referring to the article of Wang et al., 2020; Chen, 2019), the urbanization level has an impact on green total factor energy efficiency).

In order to ensure the robust regression results of the econometric model, the GTFP, ER and ICY were replaced in the model (4) respectively, and the specific model is as shown below: $\operatorname{lnGTFP2} 2_{i t}=\beta_{0}+\beta_{1} * \operatorname{lner}_{i t}+\beta_{2} * \operatorname{lnict}_{i t}+\beta_{3} * \operatorname{lnsec}_{i t}+\beta_{4} * \operatorname{lnte}_{i t}+\beta_{5} *$

$\operatorname{lnGTFP} P_{i t}=\beta_{0}+\beta_{1} * \operatorname{lner} 2_{i t}+\beta_{2} * \operatorname{lnict}_{i t}+\beta_{3} * \operatorname{lnsec}_{i t}+\beta_{4} * \operatorname{lnte}_{i t}+\beta_{5} *$ lnis $_{i t}+\beta_{6} * \operatorname{lnurban}_{i t}+\mu_{i}+\theta_{t}+\varepsilon_{i t}(6)$ 
$\operatorname{lnGTFP}_{i t}=\beta_{0}+\beta_{1} * \operatorname{lner}_{i t}+\beta_{2} * \operatorname{lnict}_{i t}+\beta_{3} * \operatorname{lnsec}_{i t}+\beta_{4} * \operatorname{lnt} e_{i t}+\beta_{5} *$

lnis $_{i t}+\beta_{6} * \operatorname{lnurban}_{i t}+\mu_{i}+\theta_{t}+\varepsilon_{i t}(7)$

\subsection{Descriptive statistics}

The data used in this paper are mainly derived from China Statistical Yearbook, China Science and Technology Statistics Yearbook, China Environmental Statistics Yearbook and China Environmental Yearbook. The starting data of patent application authorization data is available only from 2006; the latest data of industrial SO2 discharge, industrial waste discharge and environmental solid waste investment is available by 2017; More data was missing in Tibet, so the region was excluded. Hong Kong, Macao and Taiwan are the same. Therefore, limited to the data availability, we use the panel data from 30 Chinese provinces after excluding Hong Kong, Macao, Taiwan and Tibet in $2006 \sim$ in 2017. ${ }^{1}$ Specific descriptive statistics are shown in the table below:

Table 1 descriptive statistics

\begin{tabular}{ccccccc}
\hline Variable & Name & Meaning & $\begin{array}{c}\text { Sample } \\
\text { size }\end{array}$ & Mean & Min. & Max. \\
\hline Independent & Intfpch1 & GTFP & 360 & 0.69 & 0.64 & 0.72 \\
Dependent & lner4 & Environment regulation & 360 & 9.24 & 4.14 & 11.91 \\
& lnict5 & Innovation capability & 360 & 9.30 & 5.51 & 12.39 \\
Control & lnsec & Industrial added value & 360 & 8.62 & 5.90 & 10.40 \\
& lnte & Technological progress & 360 & 4.65 & 1.87 & 7.19 \\
& lnis & Industrial structure & 360 & 0.38 & 0.19 & 0.46 \\
& Inurban & Urban civilization & 360 & 0.43 & 0.26 & 0.63 \\
& Intfpch2 & GTFP & 360 & 0.69 & 0.64 & 0.74 \\
& lner3 & Environment regulation & 360 & 0.83 & 0.34 & 1.56 \\
\hline
\end{tabular}

\section{Empirical results and analysis}

\subsection{Benchmark regression analysis}

According to the Hausman test and model (4), the impact of ER and ICY on the TFP of

${ }^{1}$ Because the GTFP calculated using GML started from 2006, the 2006-2017 data were selected for empirical calculation. Environmental indicators will be available until 2017.Complete innovation index data were counted from 2006. 
green was estimated by fixed effect model. Benchmark regression results are shown in the table below. Table 2 column (1) is listed as a least square method. The results show that the ER coefficient is positive but non-significant, and the ICY is significant at the $1 \%$ significance level, indicating that ER and ICY promote GTFP (Hu et al., 2019). The column (2) of Table 2 is the control region effect, the column (3) is the control time effect, and the column (4) is the control area and time effect. The results of the columns (2)-(4) of Table 2 show that the ER coefficient is significantly positive at the $1 \%$ significance level and ICY is also significantly positive, indicating that ER and ICY promote GTFP. The government or industry departments have adopted a series of compulsory ER measures such as formulating environmental protection policies, restricting production pollution, and strict environmental certification, making enterprises have to improve the production process and technology, reduce pollution emissions, and thus improve the GTFP. At the same time, affected by environmental subsidies, green technology incentives and other incentive ERs, enterprises take the initiative to invest in the research and development of green technology innovation, and actively participate in green policy subsidy incentives, so as to improve production efficiency, and finally improve the GTFP. Innovation capability has a positive role in promoting GTFP. Because the improvement of ICY makes the wide application of innovative technology, produces technological progress and the improvement of technological efficiency, and then has a positive impact on GTFP. Benchmark regression results indicate that the hypothesis that $\mathrm{H} 1, \mathrm{H} 2$ holds.

In the control variable, The industrial added value coefficients in the columns (1)(4) in Table 2 are significantly negative, showing industrial added value has a significant inhibitory effect on GTFP, explain that as the industrial added value increases, The existing technologies in various provinces cannot inhibit the negative effects brought about by industrial production, Cause environmental load to bear the negative impact caused by industrial added value, Then inhibit the improvement of GTFP; The coefficients of technological progress in the columns (2)-(4) are significantly positive. Technical progress has been promoting GTFP, explain that, as the 
technology advances, Green production technology, pollution control technology and resource-saving technology have been developed, applied and promoted, apply these to the actual production, make the production environment technology efficiency is greatly improved. Finally, improve the GTFP; The coefficient of the industrial structure in the columns (2)-(4) is significantly positive, Industrial structure has promoted the improvement of GTFP, explaining that, along with the adjustment of the industrial structure, the output value of the tertiary industry is increasing and the secondary output value continues to decline. So that the proportion of industry has declined, the proportion of the service industry continues to rise, environmental pollution caused by the secondary industry will be greatly reduced. Then improve the GTFP. The columns (2)-(4) urbanization level is significantly positive, urbanization level of GTFP, that with the improvement of the urbanization level, urban infrastructure construction, urban public services, attract technical talents to high urbanization areas, make the region strengthened human capital, is conducive to the generation of technological innovation, and then improve GTFP. At the same time, the improvement of the urbanization rate is often accompanied by enhancing investment in environmental governance and environmental protection, which also promotes the improvement of GTFP, and thus improves the GTFP.

Table 2 Benchmark regression analysis

\begin{tabular}{ccccc}
\hline Model & $(1)$ & $(2)$ & $(3)$ & $(4)$ \\
\hline Dependent & lnGTFP & lnGTFP & lnGTFP & $\operatorname{lnGTFP}$ \\
\hline Method & OLS & FE & FE & FE \\
\hline Iner & 0.000 & $0.001^{* * *}$ & $0.001^{* *}$ & $0.001^{* * *}$ \\
& $(0.89)$ & $(4.00)$ & $(2.43)$ & $(2.87)$ \\
lnict & $0.003^{* * *}$ & $0.002^{*}$ & 0.002 & $0.002^{* *}$ \\
& $(2.71)$ & $(1.96)$ & $(1.36)$ & $(2.01)$ \\
lnsec & $-0.003^{*}$ & $-0.019^{* * *}$ & $-0.021^{* *}$ & $-0.021^{* * *}$ \\
& $(-1.76)$ & $(-8.45)$ & $(-2.35)$ & $(-8.16)$ \\
Inte & -0.001 & $0.002^{* * *}$ & $0.002^{* *}$ & $0.002^{* * *}$ \\
& $(-1.48)$ & $(2.68)$ & $(2.40)$ & $(2.46)$ \\
Inis & $-0.035^{* * *}$ & $0.052^{* * *}$ & $0.066^{* *}$ & $0.051^{* * *}$ \\
& $(-2.85)$ & $(4.70)$ & $(2.13)$ & $(4.33)$ \\
lnurban & $-0.016^{*}$ & $0.159^{* * *}$ & $0.151^{*}$ & $0.169^{* * *}$
\end{tabular}




$\begin{array}{ccccc} & (-1.70) & (6.90) & (1.78) & (6.47) \\ \text { _cons } & 0.712 * * * & 0.735 * * * & 0.735^{* *} & 0.743 * * * \\ & (117.21) & (88.20) & (2.10) & (55.08) \\ \text { Year FE } & \text { No } & \text { No } & \text { Yes } & \text { Yes } \\ \text { Province FE } & \text { No } & \text { Yes } & \text { NO } & \text { Yes } \\ \text { Observations } & 360 & 360 & 360 & 360 \\ \text { Adjusted } \mathrm{R}^{2} & & 0.23 & 0.27 & 0.27 \\ \text { Hausman } & \text { Chi-Sq.=698.45 } & & & \\ \text { test } & (\mathrm{P}=0.0000) & & \end{array}$
$\mathrm{p}<0.05$, and $\mathrm{p}<0.1$, respectively.

\subsection{The robustness test}

In order to further test the robustness of regression estimates, according to the Eq. (4) to Eq. (7) respectively, through time processing, regional processing, variable replacement, transformation of model robustness, etc., using different methods of regression results and benchmark regression, and enhance the persuasion of benchmark regression conclusion. The test results are shown in the table below.

(1) Time processing. The columns (1)-(2) in Table 3 exclude 2017 and 2006 sample data respectively, form new sample data for 2006 2016 and 2007 2017, then regression analyzed separately by a fixed effect model, although changing the coefficient of regression results and benchmarks, the direction of change in dependent and control variables is completely consistent.

(2) Regional processing. In the columns (3)-(5) in Table 3, excluding the eastern, central and western regions, they formed new samples containing only the central, regression.

(3) Variable replacement. The columns (6)-(7) in Table 3 represent the robustness test using ER replacement variables and lagging ER variables respectively. Although the regression results varied slightly from the benchmark regression, the dependent and control variables were completely consistent with the benchmark regression. 
(4) Modeling transforming. The column (8) of Table 3 performs the regression

442 analysis using Least Square Dummy Variables fixed model (LSDV). The regression

443 results showed the same significance as the benchmark regression coefficients and the

444 direction of explanatory variables ere the same too.

445

Table 3 The Robustness test

\begin{tabular}{|c|c|c|c|c|c|c|c|c|}
\hline Model & (1) & (2) & (3) & (4) & (5) & (6) & (7) & (8) \\
\hline Dependent & lnGTFP & lnGTFP & lnGTFP & lnGTFP & $\operatorname{lnGTFP}$ & $\operatorname{lnGTFP}$ & lnGTFP2 & $\operatorname{lnGTFP}$ \\
\hline Method & FE & FE & FE & FE & FE & $\mathrm{F}$ & FE & LSDV \\
\hline lner & $\begin{array}{c}0.001 * * * \\
(3.66)\end{array}$ & $\begin{array}{c}0.001 * * * \\
(3.54)\end{array}$ & $\begin{array}{c}0.001 * * * \\
(3.17)\end{array}$ & $\begin{array}{c}0.001 * * * \\
(3.32)\end{array}$ & $\begin{array}{c}0.001 * * * \\
(3.44)\end{array}$ & & $\begin{array}{l}0.000 \\
(1.05)\end{array}$ & $\begin{array}{c}0.001^{* * * *} \\
(4.00)\end{array}$ \\
\hline lnict & $\begin{array}{c}0.002 * * \\
(2.32)\end{array}$ & $\begin{array}{l}0.002 \\
(1.51)\end{array}$ & $\begin{array}{l}0.000 \\
(0.49)\end{array}$ & $\begin{array}{l}0.002 * \\
(1.84)\end{array}$ & $\begin{array}{c}0.003 * * \\
(2.44)\end{array}$ & $\begin{array}{c}0.002 * * \\
(2.15)\end{array}$ & $\begin{array}{l}0.002 \\
(1.39)\end{array}$ & $\begin{array}{l}0.002 * \\
(1.96)\end{array}$ \\
\hline Insec & $\begin{array}{c}-0.021 * * * \\
(-8.93)\end{array}$ & $\begin{array}{c}-0.015 * * * \\
(-6.48)\end{array}$ & $\begin{array}{c}-0.025^{* * * *} \\
(-11.04)\end{array}$ & $\begin{array}{c}-0.011^{* * * *} \\
(-4.27)\end{array}$ & $\begin{array}{c}-0.023^{* * *} \\
(-7.92)\end{array}$ & $\begin{array}{c}-0.016^{* * *} \\
(-7.37)\end{array}$ & $\begin{array}{c}-0.019 * * * \\
(-6.67)\end{array}$ & $\begin{array}{c}-0.019^{* * * *} \\
(-8.45)\end{array}$ \\
\hline Inte & $\begin{array}{c}0.002 * * * \\
(2.87)\end{array}$ & $\begin{array}{l}0.000 \\
(0.14)\end{array}$ & $\begin{array}{l}0.001 \\
(1.09)\end{array}$ & $\begin{array}{c}0.002 * * \\
(2.40)\end{array}$ & $\begin{array}{c}0.002 * * \\
(2.54)\end{array}$ & $\begin{array}{l}0.001 * \\
(1.93)\end{array}$ & $\begin{array}{l}0.001 \\
(1.56)\end{array}$ & $\begin{array}{c}0.002 * * * \\
(2.68)\end{array}$ \\
\hline $\operatorname{lnis}$ & $\begin{array}{c}0.046^{* * *} \\
(3.96)\end{array}$ & $\begin{array}{c}0.049 * * * \\
(4.35)\end{array}$ & $\begin{array}{c}0.098^{* * *} \\
(8.44)\end{array}$ & $\begin{array}{l}0.018 \\
(1.39)\end{array}$ & $\begin{array}{c}0.065^{* * *} \\
(4.66)\end{array}$ & $\begin{array}{c}0.056^{* * *} \\
(4.80)\end{array}$ & $\begin{array}{c}0.094 * * * \\
(6.75)\end{array}$ & $\begin{array}{c}0.052 * * * \\
(4.70)\end{array}$ \\
\hline lnurban & $\begin{array}{c}0.168^{* * *} \\
(6.89)\end{array}$ & $\begin{array}{c}0.149 * * * \\
(6.03)\end{array}$ & $\begin{array}{c}0.282^{* * *} \\
(11.19)\end{array}$ & $\begin{array}{c}0.064 * * \\
(2.56)\end{array}$ & $\begin{array}{c}0.177 * * * \\
(6.08)\end{array}$ & $\begin{array}{c}0.130 * * * \\
(5.71)\end{array}$ & $\begin{array}{c}0.214^{* * *} \\
(7.37)\end{array}$ & $\begin{array}{c}0.159 * * * \\
(6.90)\end{array}$ \\
\hline L.Iner & & & & & & $\begin{array}{l}0.001 \\
(0.65)\end{array}$ & & \\
\hline _cons & $\begin{array}{c}0.744 * * * \\
(86.33)\end{array}$ & $\begin{array}{c}0.719 * * * \\
(81.25)\end{array}$ & $\begin{array}{c}0.742 * * * \\
(94.16)\end{array}$ & $\begin{array}{c}0.718^{* * *} \\
(79.05)\end{array}$ & $\begin{array}{c}0.743 * * * \\
(61.82)\end{array}$ & $\begin{array}{c}0.730^{* * *} \\
(86.34)\end{array}$ & $\begin{array}{c}0.703 * * * \\
(65.59)\end{array}$ & \\
\hline
\end{tabular}

L.lnGTFP1

$(93.10)$

\begin{tabular}{ccccccccc} 
Year FE & No & No & No & No & No & No & No & No \\
Province FE & No & No & No & No & No & No & No & YES \\
Observations & 330 & 330 & 228 & 252 & 252 & 360 & 330 & 330 \\
Adjusted R & 0.27 & 0.18 & 0.50 & 0.11 & 0.27 & 0.18 & 0.22 & 0.83 \\
\hline
\end{tabular}

$446 \quad$ Note: The numbers in parentheses stands for robust standard error. ***, **, and * represent different significance levels, indicating $\mathrm{p}<0.01$,

$447 \mathrm{p}<0.05$, and $\mathrm{p}<0.1$, respectively.

448

\section{$449 \quad$ 4.3 Endogenous test}

450 Benchmark regression and robustness test regression controlled the appropriate

451 variables, and the empirical results demonstrated significant effects on ER, ICY, and 
GTFP. However, measurement errors of variables, omissions of potential variables, and two-way causal relationships between variables all have implications for the empirical results. Since there may be obvious differences in the intensity of ER and ICY in each province, the provinces will also differ in formulating ER and ICY, and then adjust the policies implemented by ER and ICY. At the same time, because it adopts provincial panel data in this paper, there are some missing data or some variables cannot be collected, and related variables may be left. In addition, it is possible that a two-way causal relationship between ER and ICY and green technology development, which is endogenous (Wen et al., 2019). To solve the endogenous problem, this problem verifies the causal relationship between ER, ICY and GTFP by using the lag variable as a tool variable, dynamic panel model (differential GMM) method (Yamashita, 2020). At the same time, the mechanism between the three will be analyzed later. The results of the endogenous tests are shown in the table below. Table 4 column (1) to the fourth selected ER lag variable as instrumental variable, innovation capability lag variable as instrumental variable, ER lag variable and innovation capability lag variable as the endogenous test, the column (4) to choose dynamic panel model (differential GMM), Because of less sample data, one-step estimation is used to test. The column (1)-(4) results unveil that ER has significant positive productivity; innovation productivity also has a significant positive effect. Therefore, it can be concluded that the conclusion of the relationship ER, ICY and GTFP remains unchanged, and the regression results of the benchmark regression and robustness tests are confirmed.

Table 4 Endogenous test

\begin{tabular}{ccccc}
\hline Model & $(1)$ & $(2)$ & $(3)$ & $(4)$ \\
\hline Dependent & $\operatorname{lnGTFP}$ & $\operatorname{lnGTFP}$ & $\operatorname{lnGTFP}$ & $\operatorname{lnGTFP}$ \\
\hline Method & xtivreg & xtivreg & xtivreg & GMM \\
\hline lner & $0.001 * * *$ & $0.001 * * *$ & $0.001 * * *$ & $0.000^{* * *}$ \\
& $(2.61)$ & $(2.80)$ & $(2.79)$ & $(8.68)$ \\
lnict & $0.002^{*}$ & $0.004 * *$ & $0.004 * *$ & $0.000^{* * *}$ \\
& $(1.76)$ & $(2.41)$ & $(2.40)$ & $(8.20)$ \\
lnsec & $-0.023 * * *$ & $-0.022^{* * *}$ & $-0.023 * * *$ & -0.000 \\
& $(-5.03)$ & $(-4.86)$ & $(-4.88)$ & $(-0.90)$ \\
lnte & -0.000 & -0.001 & -0.001 & $-0.001 * * *$
\end{tabular}




$\begin{array}{ccccc} & (-0.22) & (-0.68) & (-0.67) & (-16.04) \\ \text { lnis } & 0.076 * * * & 0.075 * * * & 0.076 * * * & 0.006 * * * \\ & (3.80) & (3.75) & (3.77) & (6.61) \\ \text { lnurban } & 0.191 * * * & 0.183 * * * & 0.185 * * * & 0.021 * * * \\ & (6.19) & (5.82) & (5.85) & (9.12) \\ \text { _cons } & 0.694 * * * & 0.715 * * * & 0.714 * * * & 0.017 * * * \\ & (22.07) & (21.16) & (21.13) & (7.05) \\ & & & & 0.966 * * *\end{array}$

$\begin{array}{ccccc}\text { Year FE } & \text { No } & \text { No } & \text { No } & \text { No } \\ \text { Province FE } & \text { No } & \text { No } & \text { No } & \text { No } \\ \text { Observations } & 330 & 330 & 330 & 330 \\ \text { Adjusted } \mathrm{R}^{2} & 0.24 & 0.22 & 0.22 & 0.12\end{array}$

Note: The numbers in parentheses stands for robust standard error. ***, **, and * represent different significance levels, indicating $\mathrm{p}<0.01$, $\mathrm{p}<0.05$, and $\mathrm{p}<0.1$, respectively.

\subsection{Heterogeneity test}

The previous part uses fixed effect model, panel variation factor model and dynamic panel model to find out the relationship between ER, ICY and GTFP. This part focuses on the impact of heterogeneity among the three. Since the robustness test uses regional processing, distinguishes the east, central and western processing into different sample data, and achieves consistent regression results with the benchmark regression. This part conducts heterogeneity tests of ER strength (strong and weak), ICY level (high and low), and GTFP (high and low). The relevant test results are shown in the table below. The columns (1)-(6) of Table 5 represent the regression results of high intensity ER (greater than ER mean), high ICY level (greater than ICY mean), low ICY level (less than equal to ICY mean), high GTFP (greater than GTFP mean), low GTFP (less than equal to GTFP mean). The results showed that whether the sample data is a highintensity ER, Or is low-intensity ER, All have a positive effect in promoting the GTFP; When the sample data is at a high ICY level, It has an obvious positive promotion effect on the GTFP, But when the sample data is at a low ICY level, It showed a negative relationship to the GTFP, but it was not significant, It shows that the influence of ICY level on GTFP shows a strong heterogeneity; When the sample data is high GTFP, ER, ICY is not significant at $10 \%$ significant level, when the sample data is low GTFP, ER, 
ICY has obvious positive effect on GTFP, but ICY is not significant, presents a strong difference.

497 Table 5 Heterogeneity test

\begin{tabular}{|c|c|c|c|c|c|c|}
\hline Model & (1) & (2) & (3) & (4) & (5) & (6) \\
\hline Dependent & $\operatorname{lnGTFP}$ & lnGTFP & lnGTFP & lnGTFP & $\operatorname{lnGTFP}$ & lnGTFP \\
\hline Method & FE & $\mathrm{FE}$ & FE & FE & FE & FE \\
\hline \multirow[t]{2}{*}{ lner } & $0.001 *$ & $0.001 *$ & 0.000 & $0.001 * * *$ & -0.000 & $0.001 * * *$ \\
\hline & $(1.80)$ & (1.89) & $(1.43)$ & $(3.60)$ & $(-0.06)$ & $(2.78)$ \\
\hline \multirow[t]{2}{*}{ lnict } & $0.003 *$ & 0.002 & $0.002 *$ & -0.001 & 0.001 & 0.001 \\
\hline & $(1.75)$ & (1.64) & (1.73) & $(-0.42)$ & $(1.13)$ & $(0.60)$ \\
\hline \multirow[t]{2}{*}{ lnsec } & $-0.024 * *$ & $-0.014 * *$ & -0.004 & $-0.028 * * *$ & 0.001 & $-0.022 * * *$ \\
\hline & $(-2.26)$ & $(-2.49)$ & $(-1.24)$ & $(-8.63)$ & $(0.49)$ & $(-4.39)$ \\
\hline \multirow[t]{2}{*}{ lnte } & $0.003 * * *$ & -0.000 & 0.001 & $0.002 * *$ & 0.001 & $-0.005^{*}$ \\
\hline & $(2.84)$ & $(-0.29)$ & $(1.62)$ & $(2.24)$ & $(1.16)$ & $(-1.75)$ \\
\hline \multirow[t]{2}{*}{$\operatorname{lnis}$} & 0.046 & $0.071 * * *$ & $0.030 * *$ & $0.083 * * *$ & $-0.041 * * *$ & $0.083 * * *$ \\
\hline & $(1.30)$ & $(2.91)$ & $(2.24)$ & $(3.88)$ & $(-3.23)$ & $(3.50)$ \\
\hline \multirow[t]{2}{*}{ lnurban } & $0.163 *$ & $0.161 * *$ & 0.013 & $0.323 * * *$ & $-0.044 *$ & $0.307 * * *$ \\
\hline & $(1.77)$ & $(2.67)$ & $(0.50)$ & (7.91) & $(-1.66)$ & $(6.72)$ \\
\hline \multirow[t]{2}{*}{ _cons } & $0.762 * * *$ & $0.694 * * *$ & $0.679 * * *$ & $0.746^{* * *}$ & $0.701 * * *$ & $0.705^{* * *}$ \\
\hline & $(23.10)$ & $(55.92)$ & (49.16) & (69.59) & $(58.45)$ & $(42.59)$ \\
\hline Year FE & No & No & No & No & No & No \\
\hline Province FE & No & No & No & No & No & No \\
\hline Observations & 213 & 147 & 185 & 175 & 221 & 139 \\
\hline Adjusted $\mathrm{R}^{2}$ & 0.28 & 0.33 & 0.14 & 0.51 & 0.22 & 0.44 \\
\hline
\end{tabular}

498

Note: The numbers in parentheses stands for robust standard error. ***, **, and * represent different significance levels, indicating $\mathrm{p}<0.01$, $\mathrm{p}<0.05$, and $\mathrm{p}<0.1$, respectively.

\section{Further Analysis}

The previous part detailed analyzed the impact of ER and ICY on GTFP, but it did not answer how ER and ICY affect GTFP. This part analyzes the relationship between ER, ICY and GTFP from three dimensions: spatial effect, moderating effect and mediating effect respectively.

\subsection{Spatial correlations test}

To verify the applicability of the fixed-effect model, the spatial correlation was tested. If spatial correlation exists, further spatial measurement model is needed to analyze the 


\begin{tabular}{llccccc}
\hline Year & Name & $\mathrm{I}$ & $\mathrm{E}(\mathrm{I})$ & $\mathrm{sd}(\mathrm{I})$ & $\mathrm{z}$ & $\mathrm{p}$-value* \\
\hline 2006 & $\operatorname{lnGTFP}$ & $\cdot$ & -0.034 & $\cdot$ &. &. \\
2007 & $\operatorname{lnGTFP}$ & -0.040 & -0.034 & 0.094 & -0.056 & 0.478 \\
2008 & $\operatorname{lnGTFP}$ & 0.004 & -0.034 & 0.104 & 0.372 & 0.355 \\
2009 & $\operatorname{lnGTFP}$ & 0.034 & -0.034 & 0.111 & 0.62 & 0.268 \\
2010 & $\operatorname{lnGTFP}$ & 0.052 & -0.034 & 0.113 & 0.767 & 0.221 \\
2011 & $\operatorname{lnGTFP}$ & 0.065 & -0.034 & 0.113 & 0.882 & 0.189 \\
2012 & $\operatorname{lnGTFP}$ & 0.068 & -0.034 & 0.112 & 0.913 & 0.181 \\
2013 & $\operatorname{lnGTFP}$ & 0.072 & -0.034 & 0.111 & 0.959 & 0.169 \\
2014 & $\operatorname{lnGTFP}$ & 0.071 & -0.034 & 0.11 & 0.957 & 0.169 \\
2015 & $\operatorname{lnGTFP}$ &. & -0.034 & 0.12 &. &. \\
2016 & $\operatorname{lnGTFP}$ &. & -0.034 & 0.119 &. &. \\
2017 & $\operatorname{lnGTFP}$ & 0.07 & -0.034 & 0.108 & 0.974 & 0.165 \\
\hline
\end{tabular}

Note: $* * *, * *$, and $*$ represent different significance levels, indicating $\mathrm{p}<0.01, \mathrm{p}<0.05$, and $\mathrm{p}<0.1$, respectively.

relationship between GTFP by ER and ICY; if spatial correlation does not exist, the fixed effect model is applicable. The existence of spatial correlation is usually determined by the Moran index with the formula below:

$$
\text { Moran's I }=\frac{\sum_{i=1}^{n} \sum_{i=1}^{n} W_{i j}\left(Y_{i}-\bar{Y}\right)\left(Y_{j}-\bar{Y}\right)}{\mathrm{S}^{2} \sum_{i=1}^{n} \sum_{i=1}^{n} W_{i j}}(8)
$$

Among them, $S^{2}=\frac{1}{n} \sum_{i=1}^{n}\left(Y_{i}-\bar{Y}\right) ; \bar{Y}=\frac{1}{n} \sum_{i=1}^{n} Y_{i}, \quad Y_{i}$ represents GTFP of $i$ province; the $n$ represents the total number of regions; $W_{i j}$ is the adjacency space weight matrix. The results of the spatial correlation test are shown in the table below:

The test results show that the Moran's I of 2006-2017 is not significant, except for the absence of partial data in 2006, 2015 and 2016. Which indicates that the GTFP space is irrelevant, and the fixed effect model is applicable.

\subsection{Moderating effect analysis}

In order to further test the mechanism of ER and ICY on GTFP, we refer to the verification method of Wen et al. (2005), and further verify whether ER can affect GTFP through the interaction with ICY. The specific model is shown as follows:

$\operatorname{lnGTFP}_{i t}=\alpha_{0}+\alpha_{1} * \operatorname{lner}_{i t}+\alpha_{2} * \operatorname{lnict}_{i t}+\alpha_{3} * \operatorname{lner}_{i t} * \operatorname{lnict}_{i t}+\alpha_{4} * \operatorname{lnsec}_{i t}+$ $\alpha_{5} *$ lnte $_{i t}+\alpha_{6} *$ lnis $_{i t}+\alpha_{7} * \operatorname{lnurban}_{i t}+\mu_{i}+\theta_{t}+\varepsilon_{i t}$ (9)

Among them, the $\alpha_{3}$ is the interaction coefficient of lner $_{i t}$ and lnict $_{i t}$. If the coefficient $\alpha_{1}, \alpha_{2}, \alpha_{3}$ are all significant, the moderating effect exists. I $f$ the coefficient 

$\alpha_{3}>0$ is significant, it shows that ER can have a positive impact on GTFP through interaction with ICY; otherwise, ER can have a negative impact on GTFP through interaction with ICY. Table 7 Moderating effect analysis

\begin{tabular}{|c|c|}
\hline Model & (1) \\
\hline Dependent & $\operatorname{lnGTFP}$ \\
\hline Method & Interaction \\
\hline \multirow[t]{2}{*}{ lner } & $0.001 * * *$ \\
\hline & (3.86) \\
\hline \multirow[t]{2}{*}{ lnict } & $0.002^{*}$ \\
\hline & (1.79) \\
\hline \multirow[t]{2}{*}{ lner*Inict } & 0.000 \\
\hline & $(0.72)$ \\
\hline \multirow[t]{2}{*}{ Insec } & $-0.019^{* * *}$ \\
\hline & $(-8.13)$ \\
\hline \multirow[t]{2}{*}{ lnte } & $0.002 * *$ \\
\hline & (2.59) \\
\hline \multirow[t]{2}{*}{ lnis } & $0.051 * * *$ \\
\hline & (4.54) \\
\hline \multirow[t]{2}{*}{ lnurban } & $0.159 * * *$ \\
\hline & (6.91) \\
\hline \multirow[t]{2}{*}{ _cons } & $0.734 * * *$ \\
\hline & (86.93) \\
\hline Observations & 360 \\
\hline Adjusted $\mathrm{R}^{2}$ & 0.23 \\
\hline
\end{tabular}

Note: The numbers in parentheses stands for robust standard error. $* * *, * *$, and $*$ represent different significance levels, indicating $\mathrm{p}<0.01, \mathrm{p}<0.05$, and $\mathrm{p}<0.1$, respectively.

Results tested by the moderating effect showed that the $\alpha_{3}$ coefficient was positive but not significant at the $10 \%$ significance level. It shows that ER cannot have an impact on GTFP through its interaction with ICY. Thus, the two cannot jointly affect GTFP, indicating that the moderating effect does not exist.

\subsection{Mediating effect analysis}

In order to further test whether there is an indirect effect between ER, ICY and GTFP, learn on the experience of Wen (2015) to build a mediating effect model, so as to verify whether ER can affect GTFP through ICY. The specific model is shown as follows: 


$$
\operatorname{lnGTFP} P_{i t}=\gamma_{0}+\beta_{1} * \operatorname{lner}_{i t}+\gamma_{1} * \operatorname{lnsec}_{i t}+\gamma_{2} * \operatorname{lnt} e_{i t}+\gamma_{4} * \operatorname{lni} s_{i t}+\gamma_{4} *
$$

$$
\operatorname{lnurban}_{i t}+\mu_{i}+\theta_{t}+\varepsilon_{i t}(10)
$$

$$
\operatorname{lnict}_{i t}=\gamma_{0}+\mathrm{t}_{1} * \operatorname{lner}_{i t}+\gamma_{1} * \operatorname{lnsec}_{i t}+\gamma_{2} * \operatorname{lnt}_{i t}+\gamma_{3} * \operatorname{lnis}_{i t}+\gamma_{3} *
$$

$$
\operatorname{lnGTFP} P_{i t}=\gamma_{0}+\theta_{1} * \operatorname{lner}_{i t}+\theta_{2} * \operatorname{lnict}_{i t}+\gamma_{1} * \operatorname{lnsec}_{i t}+\gamma_{2} * \operatorname{lnte}_{i t}+\gamma_{3} *
$$

$$
\text { lnis }_{i t}+\gamma_{3} * \operatorname{lnurban}_{i t}+\mu_{i}+\theta_{t}+\varepsilon_{i t} \text { (13) }
$$

If the coefficient $\beta_{1}, t_{1}, \rho_{1}$ is significant, and the coefficient $\theta_{1}<\beta_{1}$ or $\theta_{1}$ is lower than $\beta_{1}$, the mediating effect exists namely, ER have an influence on the GTFP

\begin{tabular}{|c|c|c|c|c|}
\hline Model & (1) & (2) & (3) & (4) \\
\hline Dependent & $\operatorname{lnGTFP}$ & lnict & $\operatorname{lnGTFP}$ & $\operatorname{lnGTFP}$ \\
\hline Method & Y-X1-beta1 & M-X1-t1 & Y-M-pho1 & Y-X-M-theta1 \\
\hline \multirow[t]{2}{*}{ lner } & $0.001 * * *$ & $0.018^{*}$ & & $0.001 * * *$ \\
\hline & $(4.22)$ & (1.71) & & $(4.00)$ \\
\hline \multirow[t]{2}{*}{ lnsec } & $-0.017 * * *$ & $0.929^{* * *}$ & $-0.016 * * *$ & $-0.019 * * *$ \\
\hline & $(-8.38)$ & (8.11) & $(-7.38)$ & $(-8.45)$ \\
\hline \multirow[t]{2}{*}{ Inte } & $0.002 * * *$ & $0.148^{* * * *}$ & $0.001^{* *}$ & $0.002^{* * *}$ \\
\hline & (3.15) & (3.88) & (1.98) & (2.68) \\
\hline \multirow[t]{2}{*}{ lnis } & $0.042 * * *$ & $-4.660 * * *$ & $0.054 * * *$ & $0.052^{* * * *}$ \\
\hline & (4.26) & $(-8.12)$ & (4.92) & (4.70) \\
\hline \multirow[t]{2}{*}{ lnurban } & $0.173^{* * *}$ & $7.521^{* * *}$ & $0.125^{* * *}$ & $0.159^{* * * *}$ \\
\hline & (8.00) & (6.17) & (5.72) & $(6.90)$ \\
\hline \multirow[t]{2}{*}{ lnict } & & & $0.002 * *$ & $0.002 *$ \\
\hline & & & (2.24) & (1.96) \\
\hline \multirow[t]{2}{*}{ _cons } & $0.732 * * *$ & $-0.984 * *$ & $0.729 * * *$ & $0.735^{* * * *}$ \\
\hline & (89.69) & $(-2.05)$ & (87.90) & (88.20) \\
\hline Year FE & No & No & No & No \\
\hline Province FE & No & No & No & No \\
\hline Observations & 360 & 360 & 360 & 360 \\
\hline Adjusted $\mathrm{R}^{2}$ & 0.22 & 0.92 & 0.18 & 0.23 \\
\hline $\mathrm{F}$ & 16.196 & 705.218 & 12.960 & 14.203 \\
\hline
\end{tabular}
through ICY (Zhou et al., 2019).

Table 8 mediating effect analysis 
According to the (1)-(4) regression results, ER has a significant promotion influence on GTFP, ER has a significant positive effect on ICY, ICY has a significant promotion effect on GTFP, when examining the influence of ER and ICY on GTFP, the regression coefficient of ER and ICY is significantly positive. It can be judged that the ICY has a significant mediating effect in the model. Its mediating effect was $0.018 * 0.002 / 0.001=3.6 \%$. Therefore, combined with the moderating effect and the mediating effect results, it can be believed that ER can affect the change of GTFP through ICY. The regulatory and mediating effect results suggest that the hypothesis that $\mathrm{H} 3$ holds.

\section{Conclusion and implication}

This paper selects the panel data from 30 administrative provinces and cities in China (except Hong Kong, Macao, Taiwan and Tibet) in the period from 2005 2017. First, select the input elements such as expected output and non-expected output indicators, the GTFP of 30 provinces and cities were calculated through the GML index model; Then the calculated GTFP is set as the explained variable, and ER and ICY are the explanatory variables to analyze the relationship between the three. Through robustness test, endogenous test, heterogeneity test, this study believes that ICY can promote GTFP, ER can also promote the improvement of GTFP; Moreover, compared with ER, the ICY shows obvious heterogeneity to GTFP, that is, the stronger the ICY, the stronger its effect in promoting GTFP. On the basis of spatial correlation test, the results show that there is no spatial correlation of GTFP, through moderating effect and mediating effect test, further verify the ER through interaction with the ICY to affect GTFP and ER can affect GTFP through ICY, the results show that ER can affect the change of GTFP through ICY.

Based on the above conclusion driven, this paper is making following suggestions listed below:

First, we insist on implementing policies related to ERs. The empirical results show that ERs not only facilitate the improvement of GTFP, but also positively promote 
the improvement of ICY. At the same time, the research results of different scholars show that the relationship between different ER types and GTFP presents different trends. Therefore, it is suggested that local governments continue to implement relevant policies on ER, choose appropriate ER types according to the local current situation, and strive to maximize resource benefits while protecting environmental protection. In addition, local governments should further improve the ER mechanism and clarify the governance scope, such as improving the reward and punishment system, precise subsidies for innovative enterprises, and shutting down seriously polluting enterprises.

Second, the innovation-driven development strategy is firmly implemented. The results show that ICY not only facilitates the improvement of GTFP, but also promotes it as a mediating variable of ER. Therefore, local governments should focus on the innovation-driven development strategy, further refine policies and measures, adjust the existing innovation incentive policy mechanism, and effectively reduce the innovation cost of enterprises, such as the introduction of preferential innovation incentive policies and the increase of research and development subsidies for technological innovation. In addition, we should key an eye on the innovation of systems and mechanisms, strengthen the promotion of environmental protection concepts, actively guide or support the industry to carry out the application and introduction of green innovation technologies, actively implement green transformation, strengthen environmental protection technology innovation, strengthen the guidance of green production, and realize the coordinated promotion of environmental and industrial upgrading.

Third, we will strengthen monitoring and supervision. We will strengthen the application of information technologies such as the Internet, the Internet of Things, cloud computing, and big data etc.; increase the monitoring of environmental governance, establish a big data supervision platform to collect local environmental pollution, ensure the effectiveness of central decision-making and supervision, and reduce the possibility of local governments cooperating with polluting enterprises. In addition, further optimize the implementation supervision mechanism of ER, give full 
619 play to the positive role of the Internet, and ensure smooth channels for the messes to

620 participate in environmental governance (Yang et al., 2020).

622 Abbreviations

\begin{tabular}{|l|l|}
\hline GTFP & Green total factor productivity \\
\hline TFP & Total Factor Productivity \\
\hline ICY & Innovation Capability \\
\hline ER & Environmental Regulation \\
\hline
\end{tabular}

-Ethical Approval: This is an original article that did not use other information that requires ethical approval.

-Consent to Participate: All authors participated in this article.

-Consent to Publish: All authors have given consent to the publication of this article.

-Authors' Contributions: Three authors provided critical feedback and helped shape the research, analysis, and manuscript. Chien-Chiang Lee is responsible for conceptualization and writing of the original draft; Mingli Zeng is responsible for the paper's visualization, investigation, and writing of the original draft; Changsong Wang is responsible for the overall investigation and formal analysis and writing of the original draft.

635 -Competing Interests: The authors declare that they have no competing interests. 


\section{References}

Cai, W. G., \& Zhou, X. L. (2017). Dual effect of Chinese environmental regulation on green total factor productivity. Economist. http://en.cnki.com.cn/Article_en/CJFDTotal-JJXJ201709005.htm

Cheng, Z., Li, L., \& Liu, J. (2020). Natural resource abundance, resource industry dependence and economic green growth in China. Resources Policy. https://doi.org/10.1016/j.resourpol.2020.101734

Chung, Y., Fare, R., \& Grosskopf, S. (1997). Productivity and undesirable outputs: a directional distance function approach. Microeconomics, 51(3), 229-240. https://doi.org/10.1006/jema.1997.0146

Cui, D., \& Li, B., (2019). Research on the influence mechanism of environmental regulation on technological innovation of enterprises: empirical test based on listed companies in China's heavily polluting industries. Journal of Shihezi University (Philosophy and Social Sciences). http://en.cnki.com.cn/Article_en/CJFDTotalSXZS201903008.htm

Cui, R., J, F. \& Sun, Y. (2019). A study on the change of China's interprovincial green innovation productivity and its spatial spillover effect. Macroeconomics. http://en.cnki.com.cn/Article_en/CJFDTotal-JJGA201906012.htm

Gao, W., Cheng, J., \& Zhang, J. (2019). The influence of heterogeneous. environmental regulation on the green development of the mining industry: empirical analysis based on the system GMM and dynamic panel data mode, Chinese Journal of Population Resources and Environment.17(2),154-175. https://doi.org/10.3969/j.issn.1004-2857.2019.02.006.

Gong, M., You, Z., Wang, L., \& Cheng, J. (2020). Environmental regulation, trade comparative advantage, and the manufacturing industry's green transformation and upgrading. International Journal of Environmental Research and Public Health, 17(8), 2823. https://doi:10.3390/ijerph17082823

Hai, L., \& Zhu, M. (2018). Independent research, technology spillover and regional innovation. Journal of Industrial Technological Economics. 
http://en.cnki.com.cn/Article_en/CJFDTotal-GHZJ201805016.htm

Hao, Y., Wang, L., \& Lee, C., (2018) Financial development, energy consumption and China's economic growth: New evidence from provincial panel data", International Review of Economics \& Finance, 2018. https://doi.org/10.1016/j.strueco.2020.12.001

He, W., Li, E., \& Cui, Z. (2021). Evaluation and influence factor of green efficiency of China's agricultural innovation from the perspective of technical transformation. Chinese Geographical Science, 31(2), 313-328. https://doi.org/110.1007/s11769021-1192-x

Hu, J., Zhao, W., Lian, Y., \& Huang, Q. (2018). Environmental regulation, foreign direct investment and green technological progress-evidence from Chinese manufacturing industries. International Journal of Environmental Research and Public Health, 15(2), 221-. https://doi.org/10.3390/ijerph15020221

Huang, Q., Hu J., \& Chen, X., (2018). Environmental regulation and green total factor productivity: dilemma or win-win? China Population, Resources and Environment. 11, 140-149. http://en.cnki.com.cn/Article_en/CJFDTotal-ZGRZ201811016.htm

Jing, X., \& Liu, H. (2014). Energy conservation and emission reduction environmental regulations and Chinese industrial TFP. Nanjing Journal of Social ences. http://en.cnki.com.cn/Article_en/CJFDTotal-NJSH201405005.htm

Kong, Q., Shen, C., Li, R., \& Wong, Z. (2021). High-speed railway opening and urban green productivity in the post-covid-19: evidence from green finance. Global Finance Journal, 49. https://doi.org/10.1016/j.gfj.2021.100645

Li, X., \& Wang, J., (2020). Internet development, technology spillover, and regional innovation capabilities. Science and Technology management and Research, 40(22), 7-14.

Liu, J. (2014). Research of innovation-driven development strategy accelerating the transformation of economic development mode. International Conference on Information Management. IEEE. https://ieeexplore.ieee.org/document/6703635

Liu, M., \& Xie, H., (2014). Study on the convergence of China's regional economic 
growth and environmental degradation. Science-Technology and Management. http://en.cnki.com.cn/Article_en/CJFDTotal-KUJI201402002.htm

Liu, W., Du, M., \& Bai, Y. (2021). Mechanisms of environmental regulation's impact on green technological progress-evidence from China's manufacturing sector. Sustainability, 13(4), 1600. https://doi.org/10.3390/su13041600

Nameroff, T.J., Garant, R.J. \& Albert, M.B. (2004). Adoption of green chemistry: an analysis based on us patents. Research Policy, 33(6-7), 959-974. https://doi.org/10.1016/j.respol.2004.03.001

Nyab, C. (2020). Economic crisis and innovation capability of Japan: evidence from cross-country patent citations. Technovation,

101. https://doi.org/10.1016/j.technovation.2020.102208

Oh, D. H. (2010). A global Malmquist-Luenberger productivity index. Journal of Productivity Analysis, 34(3), 183-197.https://doi.org/10.1007/s11123-010-0178-y

Porter, M. E., \& Linde, C. V. D. (1995). Toward a new conception of the environmentcompetitiveness relationship. Journal of Economic Perspectives, 9(4), 97-118. https://doi.org/10.2307/2138392

Qi, Y., (2018). Energy conservation and emission reduction, environmental regulation and China's industrial green transformation. Jiangxi Social Sciences, 3, 70-79.

Shan, H., (2008). Re-estimate of China capital stock K: 1952 2006. The Journal of Quantitative \& Technical Economics, 25(10), 17-31. http://en.cnki.com.cn/Article_en/CJFDTOTAL-SLJY200810004.htm

Shao, S., Hu, Z., Cao, J., Yang, L., \& Guan, D. (2020). Environmental regulation and enterprise innovation: a review. Business Strategy and the Environment, 29(7). https://doi.org/10.1002/bse.2446

Shen, C., Jia, N., \& Li. X., (2017). Environmental regulation and industrial green total factor productivity-empirical analysis based on CAC and MBI environmental regulations.

$\mathrm{R} \& \mathrm{D}$

Management,

2 , 144-154. http://en.cnki.com.cn/Article_en/CJFDTOTAL-YJYF201702015.htm

Song, M, \& Wang, S. (2016). Can Employment Structure Promote Environment-biased 
Technical Progress? Technological Forecasting \& Social Change, 112, 285-292. https://doi.org/10.1016/j.techfore.2016.02.016

Stoever, J., \& Weche, J. P. (2015). Environmental regulation and sustainable competitiveness: evaluating the role of firm-level green investments in the context of the porter hypothesis. Working Paper Series in Economics. 70(2), 95-114. https://doi.org/10.1007/s10640-017-0128-5

Sun, Y., \& Yang, M., (2020). Study on club convergence and source of regional gap in China. The journal of Quantitative and Technical Economics, 37(06).

Wang, C., \& Zhang, Y., (2020). Does environmental regulation policy help improve green production performance? Evidence from China's industry. Corporate Social Responsibility and Environmental Management, 27(2), 937-951.

Wang, D., \& Cao, J., (2019). Research on the Effect of Internet Development on China's total factor energy efficiency and network effect. China Population Research and Environment, 29(01), 86-95. https://doi.org/10.1002/csr.1857

Wang, W. \& Sun, F., (2018). Financial development, environmental regulation and green total factor productivity growth along the Yangtze River Economic Belt. Journal of Southwest University for Nationalities, 1, 129-137.

Wang, X. \& Wang, Y. (2021). Green Credit Policy for Enhancing Green Innovation Research. Management World, 37(06), 173-188+11

Wang, X., Fan, G. \& Liu, P. (2009). China's economic growth mode transformation and growth sustainability. Economic Research, 44(01), 4-16.

Wang, X., Liu, X., \& Xia, Y., (2020). Environmental regulation, Internet penetration rate and green total factor productivity research - takes the Yangtze River Economic Belt as an example. Coal Economy Research, 40(11), 18-24.

Wang, S., \& Han, X., (2021). Study on the Impact of Environmental Regulation on industrial transformation and upgrading-Take Beijing, Tianjin-Hebei and surrounding areas for example. SCIENCE \& TECHNOLOGY FOR DEVELOPMENT:1-14.

http://kns.cnki.net/kcms/detail/11.5286.G3.20210427.1853.035.html. 
Wen, Z., Hou, J., \& Zhang, L. (2005). Comparison and application of mediator effects and mediating effects. Psychological Abstract, 37(02), 268-274. https://www.oalib.com/paper/1464477

Wu, G., \& You, D., (2019). Influence mechanism of environmental regulation on technological innovation and green total factor productivity: based on the regulatory role of fiscal decentralization. Journal of Industrial Engineering and Engineering Management, 1, 37-50.

Wu, H., Hao, Y., \& Ren, S. (2020). How do environmental regulation and environmental decentralization affect green total factor energy efficiency: evidence from China? Energy Economics, 91, 104880. https://doi.org/10.1016/j.eneco.2020.104880

Wu. G., \& You, D. (2019). The influence mechanism of environmental regulation on technology innovation and green total factor productivity: based on the moderating effect of fiscal decentralization. Journal of Industrial Engineering and Engineering Management. (01), 37-50. http://doi.org/10.13587/j.cnki.jieem.2019.01.005

Yang, S., Yang, X., Wu, X., Wu, Y., \& Zhou J. (2021). Effect of environmental regulation on spatial and temporal differences in regional carbon emissions-based on the empirical analysis of 32 prefecture-level cities in the three northeastern provinces. Acta Scientiae Circumstantiate, 41(05), 2029-2038.

Yang, X., Wu, H., Ren, S., Ran, Q., \& Zhang, J. (2020). Does the development of the internet contribute to air pollution control in China? mechanism discussion and empirical test. Structural Change and Economic Dynamics.

Yi, F., \& Zhang, Z. (2018). Energy Efficiency, Policy and GTFP. 2018 3rd International Conference on Advances in Energy and Environment Research. https://kns.cnki.net/KCMS/detail/detail.aspx?dbcode=IPFD\&filename=XGHK20 1808001034

Yuan, B., \& Li, S. (2018). Research on innovation-driving Chinese industrial green total factor productivity under environmental regulatory policies. Industrial Economy Research, (05),101-113. https://doi.org/10.13269/j.cnki.ier.2018.05.009. 
Zhang, J., Wu, G., \& Zhang, J., (2004). Estimation of interprovincial material capital stock in China: 1952-2000. Economic Research Journal, 10, 35-44.

Zhang, Y., \& Qiao, Y., (2021). Study on Impact of Environmental Regulation on Green Total factor Productivity in Manufacturing-PSM-DID Test Based on Carbon emission Trading Policy. Ecological Economy, 37(04), 30-36.

Zhang, Y., Wang, J., Xue, Y., \& Yang, J. (2018). Impact of environmental regulations on green technologically innovative behavior: an empirical study in China. Journal of Cleaner Production, 188(JUL.1), 763-773. https://doi.org/10.1016/j.jclepro.2018.04.013

Zhao, M., Liu, F., Sun, W., \& Tao, X. (2020). The relationship between environmental regulation and green total factor productivity in China: an empirical study based on the panel data of 177 cities. International Journal of Environmental Research and Public Health, 17(15). https://doi.org/10.3390/ijerph17155287

Zhu, J., \& Wang, Y., (2019). Analysis of green total factor productivity in ChinaEmpirical test based on dynamic GMM method. Journal of Xinjiang University (Philosophy, Humanities \& Social Sciences), 47(2), 1-15.

Zhu, X., \& Huang, Y., (2021). Technological innovation and its spatial differences in China's polluting industries under the influence of green finance. Geoscience, 41(05), 777-787. 